\title{
Javanese E-Fairy Tale Book Design With Audio About Covid-19 as an Education for Prevention of Covid-19 Transmission in Children
}

\author{
Latif Nur Hasan ${ }^{1, *}$ Sri Sulistiani ${ }^{1}$ Udjang Pairin ${ }^{1}$ \\ ${ }^{1}$ Faculty of Languages and Arts, Universitas Negeri Surabaya, Indonesia \\ *Corresponding author: latifhasan@unesa.ac.id
}

\begin{abstract}
One thing that must be protected during the Covid-19 pandemic is children. Although many experts say that children are not susceptible to this virus many children are infected and some of them die. Therefore, education is needed to prevent transmission of Covid-19 in children. Education about COVID-19 for children is packaged through an electronic fairy tale book about COVID-19 in Javanese accompanied by audio. This book was developed through development procedures at level 1 , namely making designs and design assessments by experts. This study produces a book that is ready to use with expert validation results in the very good category. The validation was carried out by the Javanese language material expert with a score of 3.7. While the design expert validation got a score of 3.78 .
\end{abstract}

Keywords: Audio e-book, Covid-19, Fairy tales, Children

\section{INTRODUCTION}

The Covid-19 virus or known as Corona is a virus that was declared to appear in Wuhan City, Hubei Province, China on January 7, 2020. Indonesia is also a country affected by the Covid-19 virus. Many people say that Covid-19 is only vulnerable at the age of 50 and over. Namely, the range of $39 \%$ of all cases in the age range of 46-59 years, and $43 \%$ of cases who died aged 60 years and over. Not only affects the elderly, but Covid-19 also attacks children 0-5 years with $2.2 \%$ positive cases and $0.8 \%$ death. When viewed from the percentage, cases in children are indeed the least. However, this becomes overwhelming from the point of view that children are not yet able to take care of themselves and desperately need protection from adults.

The Indonesian Pediatric Association (IDAI) also emphasized its concern about the COVID-19 cases found in children. IDAI said that the morbidity and mortality rates for children due to Covid-19 in Indonesia are in the high category. IDAI states that it is not true if the child's age group is not susceptible to Covid-19 or is suffering from a mild illness. IDAI also seeks to urge the government or those with an interest to immediately make decisions and take actions based on the best interests of children's health and welfare (www.idai.or.id).
IDAI formulated 11 recommendations for children during this COVID-19 period. One of the eleven IDAI recommendations is that early childhood education activities should still be carried out at home in a family environment by healthy family members. Activities of school-age children and adolescents are also recommended for distance learning. It is hoped that this will avoid crowds which can increase the risk of transmission to children.

Based on the problems that have been described, it is very important to learn distance for early childhood and school children. Researchers want to make an electronic book with audio, on the theme of Covid-19 for educational efforts to prevent the spread of Covid-19 for children. It is hoped that this will make it easier for children to understand the dangers of Covid-19 and be careful, not afraid. This book supports the literacy movement for children, this book is also modified with a sound that will increase children's interest in reading books. This audiobook will also be wrapped in attractive pictures for children. Not only that, this COVID-19 story/story was made in Javanese, under which there is a translation in Indonesian. So that not only the educational substance about Covid-19 but also children can learn the Javanese language which is currently less mastered by children. So the title of this study can be formulated that is " Design Audio E-Book Tale Children 
Covid-19 Javanese as a Means of Prevention Education Pen hose Covid-19 in Children" with problems : 1) How design Audio E-Book Tales Children Covid-19 in Javanese? 2) What is the quality of the product design quality for the E-Book Audio Design for Covid-19 Children's Tales in Javanese according to the experts?

Research on the Design of Audio E-Book for Covid19 Children's Tales in Javanese as a Means of Education for the Prevention of Covid-19 Transmission in Children is a new study. As a comparison, the following describes several previous studies that have similarities and differences.

"Constructivism-Based Learning Using Animated Media with a TPCK Framework and Learning Styles on Student Achievement" [1]. This research uses the actual experimental method. The population of this study was students of class XI SMK 1 DEDAI. Data collection techniques used in this study were the test method to measure learning achievement, a questionnaire to measure learning styles, and an observation sheet to measure student learning outcomes in affective and psychomotor aspects. The results showed; 1) the learning style profile of class XI students of SMK 1 DEDAI; 2) there is an effect of constructivism-based learning using animation media on student achievement, (3) there is no influence of learning styles on student achievement, (4) there is an effect of using animation media and learning styles on student achievement.

The second study entitled "The Use of Audio-Visual Media in Learning to Listen to Fairy Tales in the Digital Age" [2]. Research on the use of audio-visual media in learning to listen to fairy tales was carried out at SDN 6 Singaparna. The research method used is a descriptive qualitative method. The enthusiasm of students in learning to listen to fairy tales using audio-visual media is better than learning to listen to tales read directly by the teacher. This can be seen from the average ability of students to listen to fairy tales. The average storytelling ability of students after using audio-visual media was 84.53 , while the average ability to listen to stories before was only 67.20. In addition to increasing the students' ability to listen to fairy tales, the use of audio-visual media also makes students more active in the learning process. This can be seen when the teacher asks several questions when the fairy tale has been played, most students respond well to the questions given by the teacher.

The third research entitled " Application of Interactive Multimedia Applications for Reading Teaching Method of Syllables and Digital Media for
Character Tales" [3]. The method of developing multimedia application tools uses the Luther method, which is a process used to assist software developers in forming a model of the software that must be made. In making this application, using strength in the form of media application assistance for drawing, animation, and authoring consists of Adobe Photoshop, Adobe Director, Adobe Flash, and Sony Vegas sound applications. Computer-assisted interactive multimedia learners can help students learn and understand how to read the syllable method with the addition of character fairy tale digital media. One of the interactive multimedia has been created to help children in learning to read the syllable method. The multimedia program is created by combining several animations, pictures, films, and games that are connected to the material for reading the syllable method. Virtual pictures are used for children to understand and learn from material by comparing with real things in our life. These interactive learning multimedia is packaged in the form of a mobile application, which can be accessed on the Google Playstore. An interactive multimedia program made for children in the Anakku Sayang Reading Class.

Based on the comparison above, it can be seen that this research has differences in terms of research themes, learning media, learning models, and evaluation instruments. While the equation is only found at the educational level of the research subject. Therefore, this research can be stated as original and different from previous studies.

Children's storybooks are very useful for improving student literacy. Children's storybooks, one of which is fairy tales, can train children's creativity through children's imagination of the story components contained in them. Nurgiyantoro [4] states that literature is present to readers, first of all, to provide entertainment, fun entertainment. Therefore, the children's storybooks that are presented need to be adapted to the characters of the children. Furthermore, Nurgiyantoro argues that "children's literature is literature emotionally, psychology can be responded to and understood by children, and generally departs from concrete facts and is easy to understand and imagine". It can be interpreted that fairy tales as one of the children's reading books must contain the child's own culture or the environment because it is following children's knowledge which must be clear and concrete.

Cullinan [5] states that "Books can play an important role in children's lives, but the role of these books depends on parents and teachers guiding them". To 
achieve this important role, teachers as parents of students in schools need a strategy to introduce books to their students. Storybooks are the right choice because storybooks will be able to attract students' interest in reading more than reading textbooks or reference books that only contain learning material. Children at elementary school age like things or readings that are fun to read, one of which is fairy tales or imaginative reading. According to Bassett, Jacka, and Logan [6] elementary school-age students have a curiosity about the natural surroundings, like to play, and enjoy trying new things. Thus, they need an interesting way to introduce or add useful knowledge to their daily lives. The storybook needed is an entertaining book and does not contain complicated material with the aim of students learning as well as getting entertainment from reading results. In connection with the phenomenon of the Covid-19 outbreak that has penetrated the entire world since the end of 2019, students need to understand Covid-19 or Corona simply so that students can take the right attitude during this pandemic.

\section{METHOD}

\subsection{Research Methods}

The method used in the development of Design Audio E-Book Tales Covid-19 Javanese this is R \& D (Research and Development or $R \& D$ ) as a result of this study is the product of Design Audio E-Book Tales Covid-19.

\subsection{Research and Development (R\&D) Procedures}

Sugiyono [7] divides Research \& Development into 4 levels. The levels of R\&D are: (1) kinds of research, produce designs, but do not test and produce them, (2) without researching, only testing existing products, (3) researching and developing existing products, and (4) researching and creating new products.

In this study, researchers used $\mathrm{R} \& \mathrm{D}$ Level 1 , namely researching, producing designs, but not testing and producing them. The following is an explanation of the steps in research and development offered by Sugiyono [7].

The first is the potentials and problems. Potential is anything that if utilized will have added value. Furthermore, the problem is a deviation between what is expected and what is happening. The second is gathering Information. After the potential and problems can be shown factually and actually, then it is necessary to collect various information that can be used as material for product planning, which is expected to solve the problem. Next, the third is product design. The products produced through research and development are expected to increase educational productivity, one of which is products that are relevant to needs. The product must be of high quality, attractive, ergonomic, and have multiple benefits. The product design is manifested in the form of an image or chart so that it can be used as a guide to assess and create it. The fourth is design validation. Design validation is an activation process to assess whether the product design will rationally be more effective or not. Design validation can be done by bringing in several experts or experienced experts to assess the new product being designed. Each expert is asked to assess the design so that its weaknesses and strengths can be identified. The last is design tested. After the design is validated by several experts who are experts in their fields, it will be known the quality of the product design.

\subsection{Data Collection Techniques}

In collecting data for research, both main data and additional data, access to various sources is needed. The following data collection techniques will be carried out during the research. The first is study of literature from several book sources, research results, and papers that have been in the seminars, and reflect on various related scientific journals. The literature review is limited to things that discuss learning, media, and children. These three fields are closely related to the material in this study. Then, the second is questionnaire, used to explore the accuracy/quality of the product design being developed. Experts who will judge are Javanese child story experts and Media / IT experts.

\subsection{Validation and Validation Aspects}

Validation is carried out on the Audio E-Book so that the quality of the E-Book Audio can be measured. Audio E-Book validation is carried out in two aspects, namely aspects of content feasibility and presentation feasibility. The validation grid for these two aspects is as follows: 
Table 1. The validation grid of content and presentation feasibility

\begin{tabular}{l|l}
\hline Criteria & Indicator \\
\hline Content eligibility & $\begin{array}{l}\text { Accuracy of educational materials } \\
\text { Up-to-date educational materials } \\
\text { Encourages Curiosity }\end{array}$ \\
\hline Serving eligibility & $\begin{array}{l}\text { Presentation Technique } \\
\text { Serving Support } \\
\end{array}$ \\
$\begin{array}{l}\text { Presentation of Leaming } \\
\text { Coherence and Sequence of Thought Plains }\end{array}$ \\
\hline
\end{tabular}

\section{RESULTS AND DISCUSSION}

\subsection{Audio Design of Covid-19 Children's Tales E-Book in Javanese}

\subsubsection{Potentials and Problems}

The stage of extracting the potential and the problem is anything that if utilized will have added value and can solve the problem is a deviation between hope and reality. The potential that can be utilized is the sophistication of technology and information today.

The sophistication of technology and information is very suitable when juxtaposed with the target of this study, namely children of the millennial generation who were born in the 2000s. Since childhood, they have been accustomed to the use of technology. The use of this technology will later be used to solve the problem of lack of knowledge on the prevention of Covid-19 in children.

\subsubsection{Gathering Information}

Based on the potential and problems that have been found, researchers chose to develop a product that can educate children about the maximum prevention of Covid-19. Of course, taking into account the characteristics of children.

Researchers chose through the media of fairy tales/children's stories because children are very familiar and happy with fairy tales. Covid-19 prevention that is too informative can be packaged like a story so that children feel that the story contains a lot of information about preventing Covid-19. The story is also not too long but packed with information.

If we look at the other characteristics of the children that they are very familiar with technology, the researchers packaged the fairy tales into an electronic fairy tale book, which is easy to store and can be easily shared. Not only that, with technology, it will be easier to add additional features that support the success of this product being developed.

As the final touch of this product, this product will be packed with attractive images and audio. This is because children have minimal reading skills and are more interested in interesting pictures and audio.

\subsubsection{Product Design}

The activities carried out at this stage are the design and implementation of product manufacturing. At the design stage, the researcher selects and determines the software that will be used for product development. There are three categories of software for product manufacturing, namely: (1) In making this image, the researcher uses paper and pencil to make a sketch, which will later be scanned. After being scanned, the sketch image is edited using the Adobe Illustration CS6 application. The editing process uses tracing. After the sketch becomes a vector file, then it is given a color according to the children's characters, (2) Making this sound entry, the researcher uses the Audacity application. Audacity can be used to record, edit, and trim audio as needed. After recording, to make children's, female, and double sound effects, the researcher used the voicefx application, (3) Combining images and sound content into an Audio E-Book, the researcher used the Foxit Reader application. Images that have been compiled are converted into files ending in .pdf. After that, the cut audio recording will be inserted.

Moreover, there is a material gathering. This stage the researchers collected materials and materials to be included in the product. The collection of this material is divided into two, namely picture material and material for the story. In picture material, to collect this material, the researcher looked for references to model images via the internet. The images you are looking for are pictures that match the characters of children. Includes an illustration of the COVID-19 virus image obtained from the internet to be modified. At this stage, the researcher determines that five sketch images will be edited into product images. These five pictures were chosen so that there weren't too many that could make the children bored. Of course, it still takes into account the complexity and appropriateness of the story's contents. Besides, in material for the story, the collection of story material is also by looking for references to existing COVID-19 stories. So that the message about Covid-19 is not wrong. Researchers also use official websites such 
as covid19.go.id to find valid information about the prevention of COVID-19 in children. Stories are arranged based on story plots that have been outlined in the sketch images. The story is divided into 5 parts according to the images that have been made.

In addition, at the assembly stage, the researchers processed the materials and materials that had been collected into a storyboard that was ready for construction. The image storyboard has been designed by researchers as follows:

Table 2. The design of image storyboard

\begin{tabular}{|c|l|}
\hline Figure 1 & $\begin{array}{l}\text { Little boys and girls are watching } \\
\text { television with their mothers, suddenly } \\
\text { there is news about the Covid-19 virus }\end{array}$ \\
\hline Figure 2 & $\begin{array}{l}\text { Coronavirus is angry or creepy between } \\
\text { the two children. The two children were } \\
\text { cheerfully wearing blankets, and } \\
\text { sneezing with high body temperatures. }\end{array}$ \\
\hline Figure 3 & $\begin{array}{l}\text { The Coronavirus was expelled by the } \\
\text { two children. The pictures illustrate as if } \\
\text { they were hero exorcists. }\end{array}$ \\
\hline Figure 4 & $\begin{array}{l}\text { The weapons of the two heroes have 6 } \\
\text { things, namely washing hands, sleeping } \\
\text { well, wearing a mask, exercising, eating } \\
\text { healthy, and just staying at home. }\end{array}$ \\
\hline Figure 5 & $\begin{array}{l}\text { It is illustrated that one family of the } \\
\text { two children is happy because they can } \\
\text { fight the coronavirus. }\end{array}$ \\
\hline
\end{tabular}

The story plan is divided into five parts. Part 1 is told that the two children were enjoying watching their favorite cartoons. But suddenly there was flash news announcing a dangerous virus from Wuhan China. The two children were afraid, but their mother tried to calm them down. Then, part 2 is told that the mother calms her two children by giving knowledge about the virus. Viruses can be killed easily so that children are not afraid. However, this section also describes the dangers of the virus so that children do not underestimate it. Part 3, it is said that children can become heroes to repel viruses so that they remain alert and not afraid. In part 4, the health protocols in this section are explained clearly and in a language that is easy for children to understand. The last part, it is said that the family is very happy because they can avoid dangerous coronavirus.

In construction/realization, based on the storyboard that has been made, realized into a picture. In the first stage, the researcher sketched the image manually using paper and pencil. After finishing the manual drawing, the image is scanned for copying onto the computer. The scanned image is then edited using the Adobe Illustration application. The editing process begins with tracing, then colored. The results of the image are as follows:

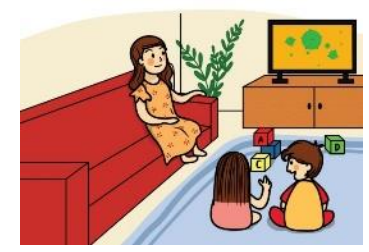

Figure 1

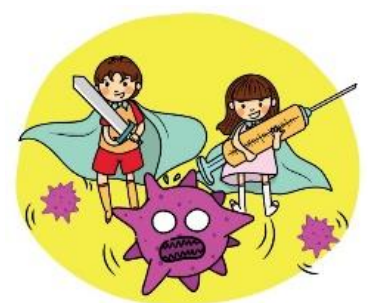

Figure 3

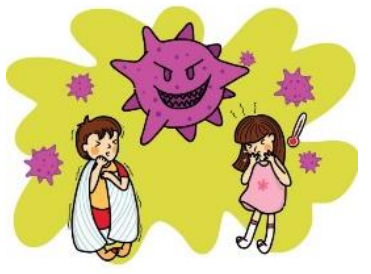

Figure 2

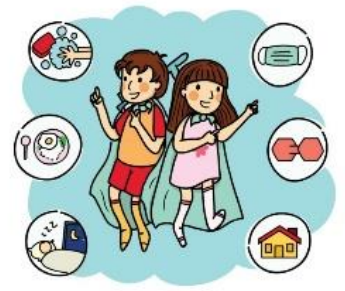

Figure 4

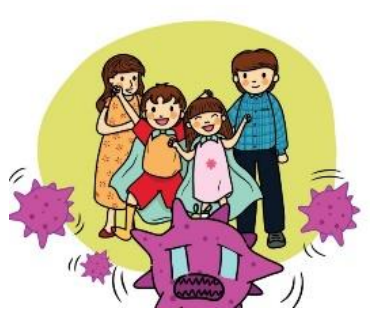

Figure 5

In the story component, the researcher constructed a 5-part design into a complete story. The stories are read and recorded via the audacity app. The reading is followed by appropriate expressions and intonations that will bring the story to life. After being recorded, the voice is edited into various kinds of voices, namely boys, girls, mothers, news readers, using the voicefx application. Stories are cut into sections, to be included in each part of the image. 
Combining images and sounds of the story using the Foxit reader application. In the application, the image is converted into a pdf, then a flare is inserted - which has been cut into 5 parts. In the top left image, there is a box that can be clicked to play the audio from the story.

The last is evaluation. Before the product design of the Audio E-Book for Covid-19 Children's Tales in Javanese was validated by experts, the researchers conducted an independent evaluation of the products that had been made. Images that were initially not written, were added with a short story. Writing is different from the audio. The difference is that writing is shorter than audio.

\subsection{Quality of Audio Design for Covid-19 Children's Tales E-Book in Javanese}

\subsubsection{Design Validation}

The process of this design validation activity is used to assess whether the product design will rationally be more effective or not. The design validation involved two experts. Design experts for the readability of image/story designs, as well as Javanese learning experts for the suitability of the material and language, used. The results of expert validation are described in the following table:

Table 3. Javanese language material expert

\begin{tabular}{l|l|l}
\hline Criteria & Indicator & $\begin{array}{l}\text { Average } \\
\text { aspect }\end{array}$ \\
\hline $\begin{array}{l}\text { Content } \\
\text { eligibility }\end{array}$ & $\begin{array}{l}\text { Accuracy of educational } \\
\text { materials } \\
\text { Up-to-date } \\
\text { materials educational } \\
\text { Encourages Curiosity }\end{array}$ & 3.8 \\
\hline $\begin{array}{l}\text { Serving } \\
\text { eligibility }\end{array}$ & $\begin{array}{l}\text { Presentation Technique } \\
\text { Serving Support }\end{array}$ & 3,9 \\
$\begin{array}{l}\text { Presentation of Learning } \\
\text { Coherence and Sequence of } \\
\text { Thought Plains }\end{array}$ & 3,6 \\
\hline
\end{tabular}

Based on the table, it can be concluded that in terms of material, it is included in the very good category, with an average of 3.7 from a maximum score of 4 .
Table 4. Design expert

\begin{tabular}{l|l|l}
\hline Criteria & Indicator & $\begin{array}{l}\text { Average } \\
\text { aspect }\end{array}$ \\
\hline $\begin{array}{l}\text { The feasibility } \\
\text { of presenting images }\end{array}$ & $\begin{array}{l}\text { Use of color } \\
\text { Go to the clear } \\
\text { illustration of the } \\
\text { image } \\
\begin{array}{l}\text { The suitability of the } \\
\text { image to the story } \\
\text { Compatibility of the } \\
\text { image with the } \\
\text { reading target }\end{array}\end{array}$ & $3,8.8$ \\
\hline
\end{tabular}

Based on the table, it can be concluded that in terms of the feasibility of the image design it is also included in the very good category, with an average of 3.78 from a maximum score of 4 .

\subsubsection{Tested Design}

After the design has been validated by two experts who are experts in their fields, it is known that the quality of the design of the Audio E-Book product for Covid-19 Children's Tales in Javanese is very good, with a score of 3.74. Based on the two experts, the product design of the Audio E-Book for the Tales of Covid-19 Children in Javanese could be continued for further testing.

\section{CONCLUSION}

Based on the results of this study, it can be concluded that storybooks about COVID-19 for children are suitable for adequate audio-visual design. This is to facilitate children's understanding of the story. The book that has been developed is also ready to be used as a tool for hazard education and handling of Covid-19 in children.

\section{REFERENCES}

[1] H. Darmawan, "Pembelajaran berbasis konstruktivisme menggunakan media animasi dengan kerangka kerja TPCK dan gaya belajar terhadap prestasi belajar siswa," Form. J. Ilm. Pendidik. MIPA, vol. 6, no. 1, pp. 1-11, 2016. Available: 10.30998/formatif.v6i1.747.

[2] R. Z. Nurani, F. Nugraha, and G. S. Sidik, "Penggunaan media audio visual dalam pembelajaran menyimak dongeng di era digital," EduHumaniora | J. Pendidik. Dasar Kampus 
Cibiru, vol. 10, no. 2, p. 78, 2018, Available: 10.17509/eh.v10i2.10867.

[3] A. Khudori, "Penerapan Aplikasi multimedia interaktif pembelajaran membaca metode suku kata dan digital," Teknol. Humanis di Era Soc. 5.0, no. e-ISSN: 2685-5615, pp. 161-164, 2019.

[4] B. Nurgiyantoro, Sastra Anak: Pengantar
Pemahaman Dunia Anak. 2018.

[5] H.G. Tarigan, Dasar-Dasar Psikosastra. 2011.

[6] M. Sumantri et al, Stategi Belajar Mengajar. 1999.

[7] Sugiyono, Metode Penelitian Kuantitatif, Kualitatif dan R\&D. 2008. 